\title{
beta I-integrin mediates myelin-associated glycoprotein signaling in neuronal growth cones
}

\author{
Eyleen LK Goh ${ }^{\dagger 1,2}$, Ju Kim Young ${ }^{\dagger 1,2}$, Kenichiro Kuwako ${ }^{3}$, Marc Tessier- \\ Lavigne $^{4}$, Zhigang $\mathrm{He}^{3}$, John W Griffin ${ }^{2,5}$ and Guo-li Ming*1,2,5
}

\begin{abstract}
Address: ${ }^{1}$ Institute for Cell Engineering, The Johns Hopkins University School of Medicine, MD 21205, USA, ${ }^{2}$ Department of Neurology, The Johns Hopkins University School of Medicine, MD 21205, USA, ${ }^{3}$ Division of Neuroscience, Children's Hospital, Boston, MA 02115, USA, ${ }^{4}$ Division of Research, Genentech, 1 DNA Way, South San Francisco, CA 94080, USA and ${ }^{5}$ The Solomon H. Snyder Department of Neuroscience, The Johns Hopkins University School of Medicine, MD 21205, USA

Email: Eyleen LK Goh - egoh2@jhmi.edu; Ju Kim Young - jkim241@jhmi.edu; Kenichiro Kuwako - kuwako1107@yahoo.co.jp; Marc TessierLavigne-marctl@gene.com; Zhigang He - zhigang.he@childrens.harvard.edu; John W Griffin - jgriffi@jhmi.edu; Guo-

li Ming* -gming1@jhmi.edu

* Corresponding author †Equal contributors
\end{abstract}

Published: 15 October 2008

Molecular Brain 2008, I:10 doi:10.1186/1756-6606-1-10

This article is available from: http://www.molecularbrain.com/content/I/I/10

(c) 2008 Goh et al; licensee BioMed Central Ltd.

This is an Open Access article distributed under the terms of the Creative Commons Attribution License (http://creativecommons.org/licenses/by/2.0), which permits unrestricted use, distribution, and reproduction in any medium, provided the original work is properly cited.
Received: 6 October 2008

Accepted: 15 October 2008

\begin{abstract}
Several myelin-associated factors that inhibit axon growth of mature neurons, including Nogo66, myelin-associated glycoprotein (MAG) and oligodendrocyte myelin glycoprotein (OMgP), can associate with a common GPI-linked protein Nogo-66 receptor (NgR). Accumulating evidence suggests that myelin inhibitors also signal through unknown NgR-independent mechanisms. Here we show that MAG, a RGD tri-peptide containing protein, forms a complex with $\beta I$-integrin to mediate axonal growth cone turning responses of several neuronal types. Mutations that alter the RGD motif in MAG or inhibition of $\beta \mathrm{I}$-integrin function, but not removal of $\mathrm{NgRs}$, abolish these MAG-dependent events. In contrast, OMgp-induced repulsion is not affected by inhibition of blintegrin function. We further show that MAG stimulates tyrosine phosphorylation of focal adhesion kinase (FAK), which in turn is required for MAG-induced growth cone turning. These studies identify $\beta \mathrm{I}$-integrin as a specific mediator for MAG in growth cone turning responses, acting through FAK activation.
\end{abstract}

\section{Background}

Myelin-associated glycoprotein (MAG), a component of myelin in the central and peripheral nervous system, promotes neurite outgrowth during the embryonic development, but inhibits axonal regeneration in the adult nervous system [1-9]. Following damage to the adult CNS, disruption of the myelin sheath leads to the release in abundance of a soluble fragment containing the MAG extracellular domain, which possesses potent inhibitory activity for neurite outgrowth [10]. A receptor complex consisting of NgR, p75/TROY and Lingo-1 has been shown to mediate the inhibitory activities of three major myelin-associated inhibitors: MAG, Nogo66 (an extracellular domain of NogoA) and OMgp [11-19]. While certain classes of neurons from p75 knockout mice exhibit reduced responses to myelin inhibitors, several types of neurons lacking NgRs are still inhibited by these factors [20-23]. In particular, a recent study using NgR germ-line knockout mice and short-hairpin RNA (shRNA) interference suggests that $\mathrm{NgR}$ is only partially involved in the acute growth cone collapse induced by MAG and OMgp, but may not be required for the long-term growth inhibi- 
tory actions of these two factor [22]. Thus, it is likely that an additional signaling mechanism is critical for transducing the signaling of MAG and possibly other myelin-associated inhibitors.

Integrins, consisting of $\alpha$ and $\beta$ chains, are heterodimeric receptors for components of the extracellular matrix and for specific ligands [24]. Extensive studies have shown that integrins are important for cytoskeleton dynamics, cell adhesion and migration [25]. Emerging evidence also suggests that integrins regulate neurite extension, axonal guidance and neuronal migration through direct or indirect mechanisms [26]. Many downstream signaling of guidance cues and integrins converges onto common pathways that regulate cytoskeleton rearrangement, thus integrins and guidance cues could also modulate effects of each other [27-30]. In addition, exogenous laminin as a substrate impedes MAG and myelin inhibitory activity on neurite initiation and outgrowth [31,32]. These results suggest the existence of competitive crosstalk between integrin ligands and inhibitory factors associated with myelin and glia scar.

Here we demonstrated that $\beta 1$-integrin acts as a receptor for MAG to mediate growth cone responses independent of NgRs in mammalian neurons. Our study identifies a novel signaling mechanism for MAG and may have significant implications for therapeutic modulation of MAG functions in the adult nervous system.

\section{Results}

\section{MAG interacts with $\beta I$-integrin}

Human and rodent MAG (also called Siglec-4) contain the RGD tri-peptide (Fig. 1A), a characteristic binding motif recognized by integrin receptors containing $\beta 1$ or $\beta 3$ subunits [33,34]. Crystal structure analysis and modeling $[35,36]$ suggest that the RGD motif in MAG (located within the F-strand, Fig. 1A) is not hidden from the protein surface as previously thought $[37,38]$. To determine whether $\beta 1$-integrin interacts with MAG, we treated cultured primary hippocampal neurons with recombinant MAG consisting of the MAG extracellular domain fused to human Fc, a fusion protein previously shown to potently regulate neurite outgrowth when present uniformly and induce growth cone turning responses when applied locally $[2,12,13,39-41]$. MAG and $\beta 1$-integrin were coimmunoprecipitated with antibodies directed against either $\beta 1$-integrin or human Fc fragment (Fig. 1B, C), suggesting that these two proteins interact with each other. In contrast, native human Fc fragment and $\beta 1$-integrin were not co-immunoprecipitated under the same condition (Fig. 1C). To further examine whether MAG directly interacts with $\beta 1$-integrin, we purified recombinant protein of GST fused to the extracellular domain of $\beta 1$-integrin. Pulldown experiments showed that GST- $\beta 1$-integrin directly binds MAG-Fc, but not the native Fc fragment, in a cell free environment (Fig. 1D).

We next examined the requirement of the RGD motif in MAG for its association with $\beta 1$-integrin. Biochemical analysis showed that the association between MAG and $\beta 1$-integrin was attenuated by the disintegrin echistatin, a viper-venom-derived RGD peptide that specifically inhibits $\beta 1$ and $\beta 3$ containing integrins [42], and by $\mathrm{Ha} 2 /$ 5 , a specific $\beta 1$-integrin function blocking antibody [43](Fig. 1E). We also constructed a mutant form of MAG (Fig. 1A), in which the RGD motif was mutated to KGE (MAG-KGE) and is not recognized by integrins [44]. Under the same experimental condition, purified MAGKGE was unable to interact with $\beta 1$-integrin whereas purified MAG-RGD (wild-type) could (Fig. 1C). Taken together, these results demonstrated that the association between MAG and $\beta 1$-integrin is direct and occurs via a classical mode of integrin-ligand interaction[33,34].

\section{$\beta I$-integrin function is required for MAG-induced growth cone response}

To examine the functional role of $\beta 1$-integrin in transducing MAG signaling in neurons, we performed growth cone turning assays using rat hippocampal neurons [41,45] [See Materials and methods]. Consistent with earlier findings of repulsive growth cone responses of spinal neurons to MAG gradients $[2,12,13,39-41]$, axonal growth cones of postnatal day 5 (P5) hippocampal neurons also exhibited repulsive responses in a microscopic gradient of recombinant MAG $(150 \mu \mathrm{g} / \mathrm{ml}$ in the pipette; Fig. 2A). However, the growth cones showed no bias in the direction of axonal extension with heat-inactivated MAG-FC (MAG-HI) or native Fc fragment (Fig. 2D). The repulsive responses were completely abolished in the presence of $100 \mathrm{nM}$ echistatin or $1.0 \mu \mathrm{g} / \mathrm{ml} \mathrm{Ha} 2 / 5$ (Fig. 2B, D), but not by the control IgM (Fig. 2D). Significant repulsive responses remained in the presence of a specific $\beta 3$ integrin function-blocking antibody [see Additional file $1]$, suggesting the specific involvement of $\beta 1$-integrin in mediating MAG induced growth cone response. Indeed, neurons transfected with specific shRNAs against $\beta 1$ integrin [see Additional file 1], but not control shRNA, abolished growth cone responses to the MAG gradient [see Additional file 1]. Additionally, we generated two MAG mutants lacking an intact RGD motif: MAG-KGE or MAG-RAD. Gradients of mutant MAG proteins failed to induce significant growth cone response of these neurons (Fig. 2C \&2D). Taken together, these results demonstrated that $\beta 1$-integrin function is required for MAG-induced axonal growth cone repulsive response of postnatal hippocampal neurons.

To further characterize whether $\beta 1$-integrin plays a permissive or an instructive role in MAG signaling, hippoc- 
A

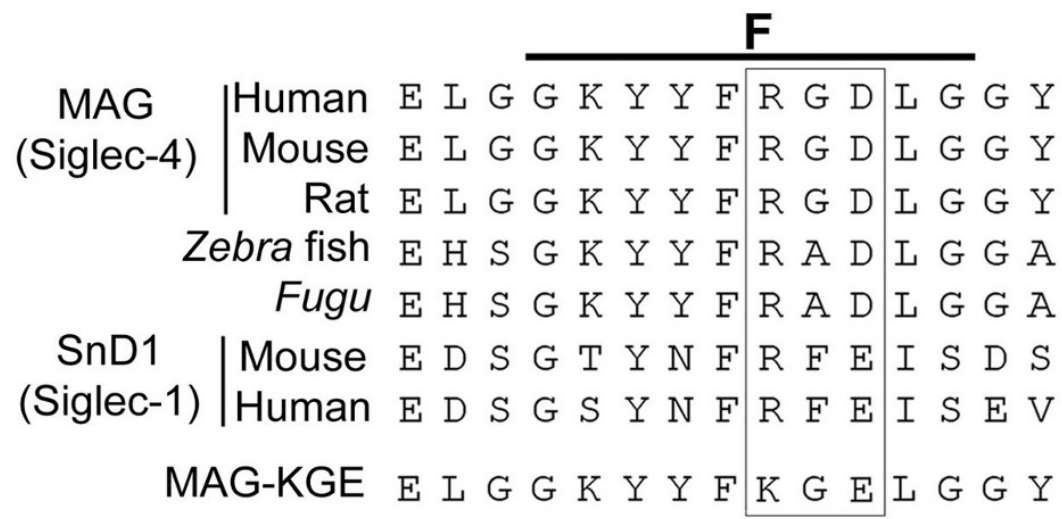

B

MAG-Fc 02

C $(\mu \mathrm{g} / \mathrm{ml})$

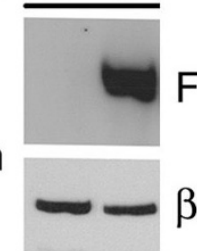

FC

IP:

$\beta 1$-integrin

IP: Fc

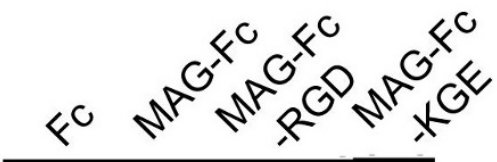

$\beta 1$-integrin

- 31 -integrin

D

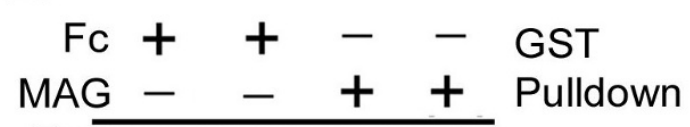

$-\mathrm{Fc}$

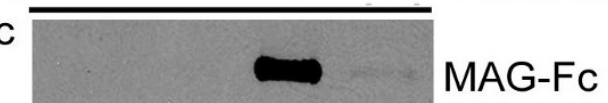
MAG-Fc -+-+-+-+
$\mathrm{Ha} 2 / 5--++---0.5 \mu \mathrm{g} / \mathrm{ml}$
$\mathrm{Ha} 2 / 5----++--2.0 \mu \mathrm{g} / \mathrm{ml}$
Echistatin $-----++100 \mathrm{nM}$

IP:

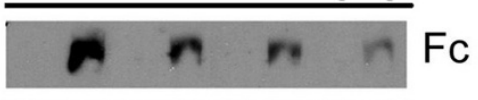

$\beta 1$-integrin

$\beta 1$-integrin

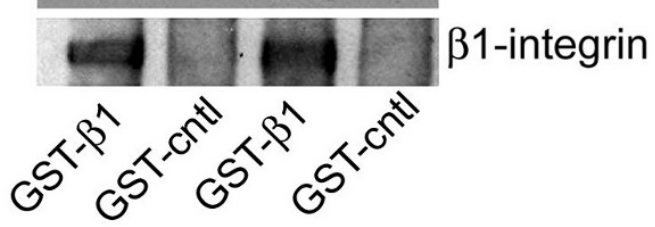

\section{Figure I}

Association between MAG and $\beta I$-integrin in primary hippocampal neurons. A. Sequence alignment of the RGD motif in the F-strand of MAG (Siglec-4) and SnDI (Siglec-I) from different species. B-E. Association between MAG and $\beta I-$ integrin. Primary hippocampal cultures were treated with wild-type MAG-Fc (RGD), mutant MAG-Fc (KGE), or native Fc fragment, in the presence or absence of echistatin $(100 \mathrm{nM})$ or $\mathrm{Ha} 2 / 5(0.5$ or $2.0 \mu \mathrm{g} / \mathrm{ml})$. Cell lysates were immunoprecipitated with antibodies raised against $\beta I$-integrin and subjected to immunobloting for human $F c$ fragment, or vice versa (B, C, E). In GST pull-down experiments (D), purified GST- $\beta$ I-integrin (extracellular domain) or GST control was incubated with MAG-Fc or native Fc fragment, and GST pull-down was subjected to western blot analysis and immunobloting for the Fc fragment. 


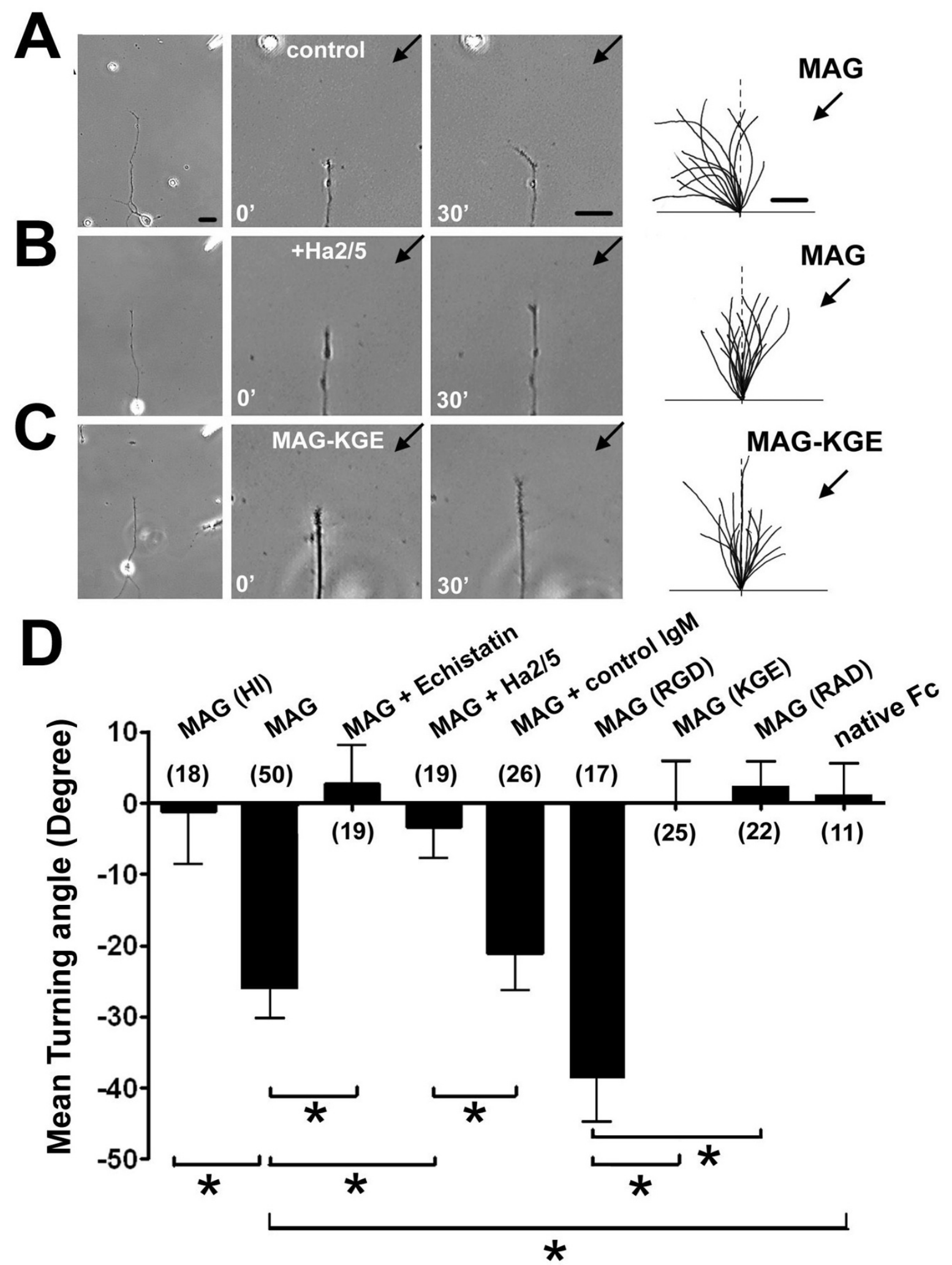

Figure 2 (see legend on next page) 
Figure 2 (see previous page)

$\beta I$-integrin function is essential for MAG-induced axonal growth cone repulsion of hippocampal neurons. A-C, Growth cone turning in a gradient of MAG $(150 \mu \mathrm{g} / \mathrm{ml}$ in the pipette). Sample images show the axons of P5 rat hippocampal neurons in the gradient for 30' on the left and axonal growth cones at the onset $\left(0^{\prime}\right)$ and at the end $\left(30^{\prime}\right)$ of the turning assay at a higher magnification. Scale bar: $20 \mu \mathrm{m}$. Right traces show sample trajectories of axons during the turning assay from I 5 randomly selected neurons. Scale bar: $5 \mu \mathrm{m}$. D. Summary of growth cone turning angles under different conditions. Similar as in (A-C), growth cones were subjected a gradient of MAG-Fc, heat-inactivated (HI) MAG, wild-type (RGD) and mutant forms (KGE, RAD) of MAG-Fc, or native human Fc fragment. Pharmacological reagents were preincubated for 30 min and present throughout the turning assay with the following concentrations: echistatin ( $100 \mathrm{nM}) ; \mathrm{Ha} 2 / 5$ (I $\mu \mathrm{g} / \mathrm{ml})$; Control lgM (I $\mu \mathrm{g} / \mathrm{ml})$. Data represent mean \pm s.e.m. Numbers associated with bars indicate the number of growth cones analyzed under each condition. "*" indicates significant difference $(p<0.0$ I, ANOVA).

ampal neurons were uniformly activated by MAG in the bath $(150 \mathrm{ng} / \mathrm{ml})$ and exposed to a gradient of $\mathrm{Ha} 2 / 5(0.5$ $\mathrm{mg} / \mathrm{ml}$ in the pipette) to generate a reverse gradient of $\beta 1$ integrin activation within the growth cone (Fig. 3A). Interestingly, neuronal growth cones exhibited significant attractive responses under this condition (Fig. 3A, C). In contrast, a control gradient of saline in the presence of uniform MAG (Fig. 3B), or a gradient of $\mathrm{Ha} 2 / 5$ in the absence of $M A G$, produced no significant growth cone turning responses (Fig. 3C). These results further demonstrated an essential role of $\beta 1$-integrin in MAG-induced growth cone responses of hippocampal neurons. In another set of experiments, hippocampal neurons were subjected to the MAG gradient in the presence of bath application of a peptide consisting of five amino acid YIGSR, which has been previously shown to bind and activate $\beta 1$-integrin, to saturate the $\beta 1$-integrin signaling [46]. The repulsion to MAG was abolished by this uniform application of YIGSR, but not by a control peptide IKVAV (Fig. 3D). Thus, $\beta 1$-integrin signaling appears to play an instructive rather than a permissive role in MAG-induced growth cone responses.

It is known that MAG exhibits differential effects on neurons at different developmental stages and, in particular, promotes neurite outgrowth of embryonic neurons $[1,3,6,47]$. We therefore tested whether $\beta 1$-integrin also mediates growth cone responses of embryonic neurons to MAG. Interestingly, axonal growth cones of E17 rat hippocampal neurons exhibited significant attractive responses in the same MAG gradient, consistent with the growth promoting role of MAG on young neurons (Fig. 4A). Such MAG-induced response was also abolished in the presence of $\mathrm{Ha} 2 / 5(1.0 \mu \mathrm{g} / \mathrm{ml}$; Fig. 4A). Neuronal responses to MAG are modulated by CAMP/PKA signaling $[41,48]$. Indeed, MAG-induced attractive responses of E17 neurons was converted to repulsive responses in the present of a PKA inhibitor Rp-cAMPS $(20 \mu \mathrm{M})$, while MAG-induced repulsive responses of P5 hippocampal neurons was converted to attractive responses in the presence of a PKA activator Sp-cAMPS (20 $\mu \mathrm{M}$; [see Additional file 2]). Importantly, all these MAG-induced growth cone responses were abolished in the presence of $\mathrm{Ha} 2 / 5$ [see Additional file 2]. Thus, $\beta 1$-integrin mediates MAGinduced growth cone responses of hippocampal neurons at different developmental stages and under different cellular status.

To determine whether the function of MAG-integrin interactions are limited to hippocampal neurons, we examined growth cone responses of postnatal rat cerebellar granule cells [45]. Axonal growth cones of these neurons exhibited significant repulsive responses in the MAG gradient (150 $\mu \mathrm{g} / \mathrm{ml}$ in the pipette; Fig. $4 \mathrm{~B})$. Importantly, MAG-induced repulsion of these neurons was also abolished in the presence of $\mathrm{Ha} 2 / 5(1.0 \mu \mathrm{g} / \mathrm{ml}$; Fig. 4B). These results show that $\beta 1$-integrin function is required for MAG-induced growth cone responses in different types of mammalian CNS neurons.

\section{$\beta I$-integrin function is not required for OMgp-induced growth cone turning}

Three major myelin-associated inhibitory factors, Nogo66, MAG and OMgp, are known to bind to the common $\mathrm{NgR}$ protein and may utilize the same signal transduction pathway to regulate axonal behaviours [11-14]. Therefore, we next sought to determine whether $\beta 1$-integrin also mediates growth cone responses to other myelin-associated inhibitors. Axonal growth cones of rat P5 hippocampal neurons exhibited significant repulsive turning responses to a gradient of recombinant OMgp $(5 \mu \mathrm{g} / \mathrm{ml}$ in the pipette), but not to Nogo-66 (data not shown) or to heat-inactivated OMgp (Fig. 5A, C). In contrast to our observations for MAG, axonal growth cones still exhibited significant repulsive response to OMgp in the presence of either echistatin or $\mathrm{Ha} 2 / 5$ (Fig. 5B, C). Thus, $\beta 1$-integrin appears to specifically mediate axonal growth cone responses induced by MAG, but not by OMgp.

\section{$\beta I$-integrin mediates MAG-induced growth cone turning independent of $\mathbf{N g R}$}

To address whether $\beta 1$-integrin provides an independent pathway to mediate MAG signaling or acts as a co-receptor along with NgR/p75/TROY/Lingo-1, we examined growth 

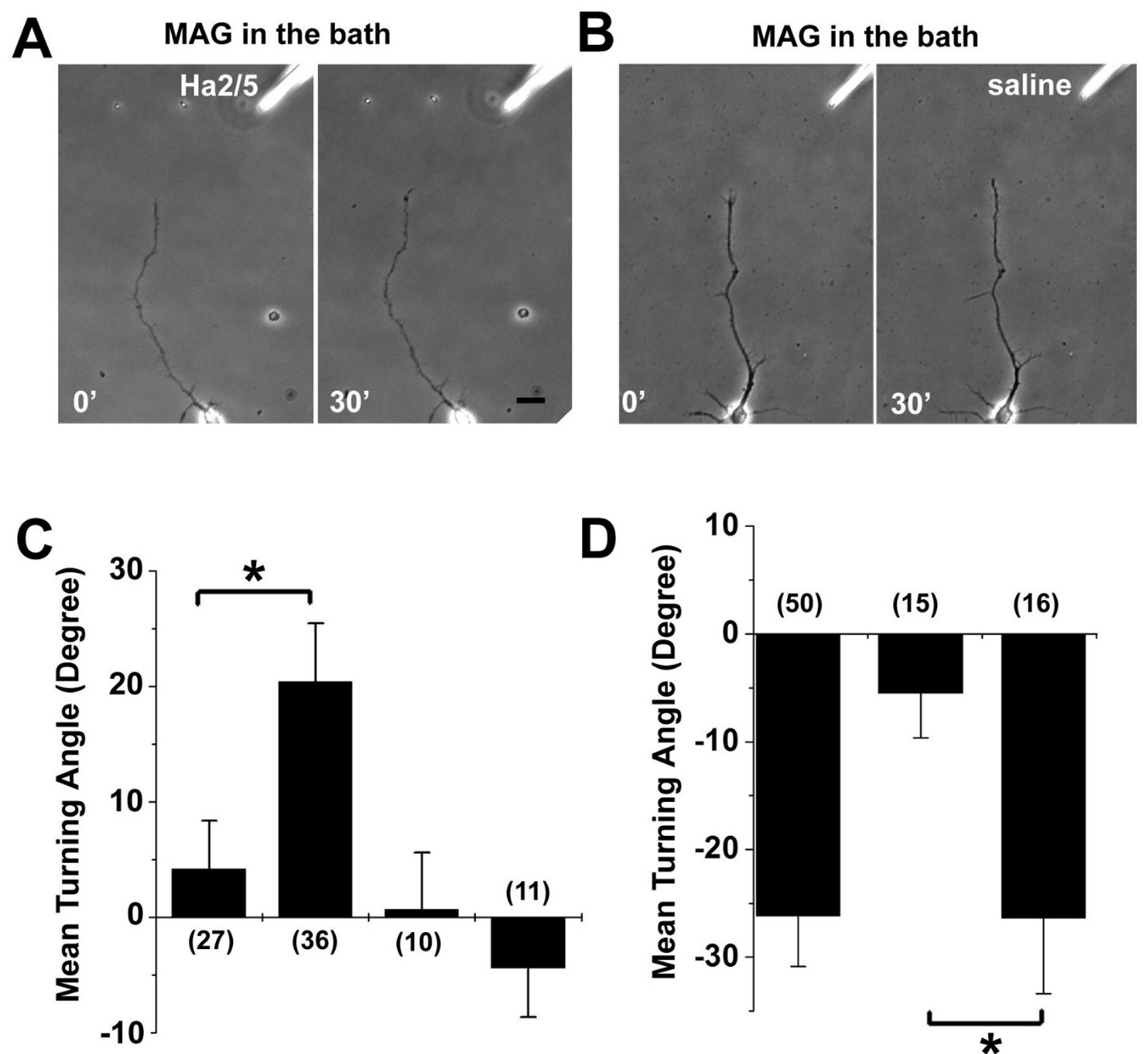

\section{bath MAG MAG saline saline gradient saline $\mathrm{Ha} 2 / 5 \mathrm{Ha} / 5$ saline}
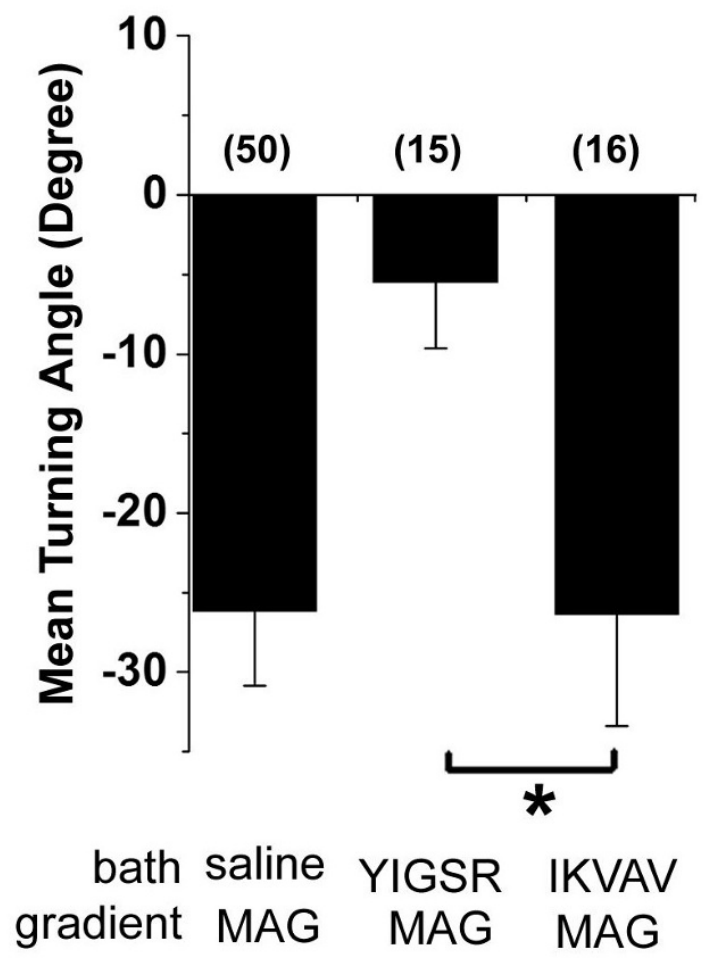

Figure 3

$\beta \mathrm{I}$-integrin plays an instructive role in MAG-induced growth cone turning. A-C. Growth cone turning in the presence of uniform activation by MAG. Shown are sample images of growth cone turning of P5 rat hippocampal neuron axons in a gradient of $\mathrm{Ha} 2 / 5(0.5 \mathrm{mg} / \mathrm{ml}$ in the pipette, A) or saline (B) with uniform presence of MAG (I50 ng/ml) in the bath. Scale bar: $20 \mu \mathrm{m}$. Also shown is the summary of growth cone turning angles under different conditions, $\mathrm{C})$. Values represent mean \pm s.e.m. Numbers associated with the bar graph indicate the number of growth cones analyzed. "*" indicates significant difference $(p<0.0 \mathrm{I}, \mathrm{ANOVA})$. D. MAG-induced growth cone turning in the present of uniform activation of $\beta \mathrm{I}$-integrin. Same as in (C), except that neurons were subjected to a MAG gradient (I50 $\mu \mathrm{g} / \mathrm{ml}$ in the pipette) with uniform presence of the $\beta I$-intergin activating peptide YIGSR $(10 \mu \mathrm{g} / \mathrm{ml})$, or the control peptide LKVAV $(10 \mu \mathrm{g} / \mathrm{ml})$, respectively. 

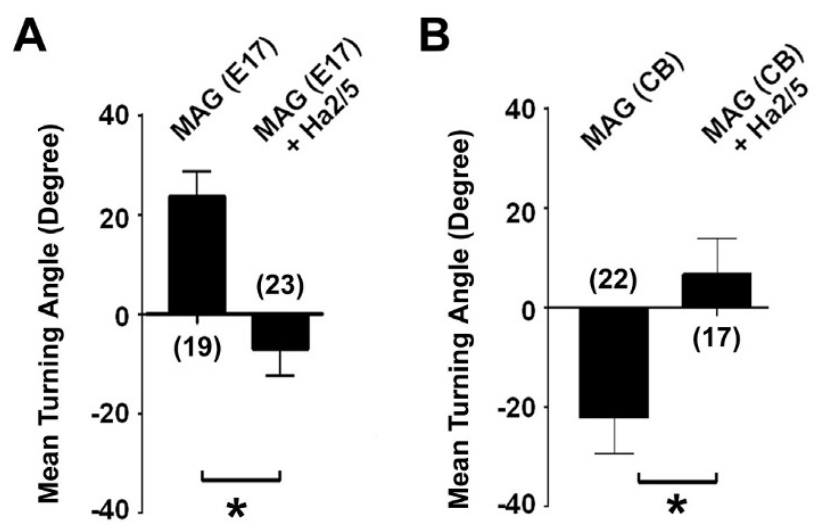

Figure 4

$\beta I$-integrin mediates MAG-induced turning responses of embryonic hippocampal neurons and postnatal cerebellar neurons. Shown is the summary of turning angles for axonal growth cones of rat EI7 hippocampal neurons and P5 cerebellar neurons (CB) in a gradient of MAG $(150 \mu \mathrm{g} / \mathrm{ml}$ in the pipette), with or without the presence of $\mathrm{Ha} 2 / 5(\mathrm{I} .0 \mu \mathrm{g} / \mathrm{ml})$. Values represent mean \pm s.e.m. Numbers associated with the bar graph indicate the number of growth cones analyzed. "*" indicates significant difference $(p<0.0$ I, ANOVA $)$.

cone responses following the removal of GPI-linked proteins, including all NgRs, from the neuronal cell surface $[13,14]$. Primary hippocampal neurons were pre-treated with PI-PLC (1 unit/ml) for $30 \mathrm{~min}$ and then growth cones were examined in the MAG gradient with the continuous presence of PI-PLC. Under these conditions, axonal growth cones of P5 rat hippocampal neurons still exhibited significant repulsive turning responses to MAG (Fig. 6A). Biochemical analysis confirmed that the PI-PLC treatment was effective in removing $\mathrm{NgR}$ from these primary neurons [see Additional file 3], but the binding of MAG to $\beta 1$-integrin was not affected [see Additional file $3]$. These results are consistent with a number of previous findings that MAG retains its ability to induce RhoA activation [20] and inhibit neurite outgrowth[23] in postnatal cerebellar granule cells following the PI-PLC treatment, while mutant forms of MAG-Fc lacking an intact RGD domain (AGD or DGD) lose their inhibitory activities on axonal extension of cultured cerebellar granule cells [49].

To directly assess the specific role of NgR in MAG-induced growth cone responses, we examined neurons from $\mathrm{NgR}$ null mice [21]. Mouse hippocampal neurons lacking NgR still exhibited significant repulsive responses to the MAG gradient (Fig. 6B), suggesting that $\mathrm{NgR}$ is dispensible for MAG-induced growth cone repulsion. More importantly, MAG-induced repulsion of neurons lacking $\mathrm{NgR}$ was also abolished by $\mathrm{Ha} 2 / 5$ (Fig. 6B). In addition, we were unable to detect interactions between $\beta 1$-integrin and any member of the known NgR signaling complex, including $\mathrm{NgR}$, p75, TROY and Lingo-1, either in the presence or absence of MAG [see Additional file 4]. Taken together, these findings are consistent with the notion that $\beta 1$-integrin mediates MAG-induced growth cone responses independent of the known NgR receptor complex.

\section{FAK mediates MAG-induced growth cone turning downstream of $\beta$ I-integrin}

How does $\beta 1$-integrin signaling transduce MAG-induced growth cone responses? Focal adhesion kinase (FAK) is a major mediator of integrin-dependent signaling in many contexts, including cell migration and axon guidance $[26,50,51]$. Interestingly, treatment of hippocampal neurons with MAG $(2 \mu \mathrm{g} / \mathrm{ml})$ induced tyrosine phosphorylation of FAK in a time-dependent manner (Fig. 7A). Such MAG-induced tyrosine phosphorylation of FAK was abolished in the presence of echistatin (100 nM) or Ha2/5 (2.0 $\mu \mathrm{g} / \mathrm{ml}$; Fig. 7B). In addition, mutant MAG-KGE failed to trigger tyrosine phosphorylation of FAK (Fig. 7C) while removing GPI-linked proteins following the PI-PLC treatment did not affect MAG-induced phosphorylation of FAK in these neurons [see Additional file 5]. Thus, MAG induces tyrosine phosphorylation of FAK in an integrindependent manner.

We further examined specific tyrosine residues of FAK that are phosphorylated upon MAG stimulation in hippocampal neurons. As shown with site-specific phospho-tyrosine FAK antibodies, MAG induced a significant increase in the phosphorylation of FAK at tyrosine residues 397 and 861 (Fig. 7D). Similar $\beta 1$-integrin-dependent phosphorylation of FAK these tyrosine residues were also found in embryonic cortical neurons treated with MAG (data not shown).

To determine the functional role of FAK and its tyrosine phosphorylation in MAG-induced growth cone turning, we transfected P5 rat hippocampal neurons with shRNA constructs to knockdown the expression of endogenous FAK [see Additional file 5]. Expression of shRNA-FAK, but not control shRNA, abolished MAG-induced repulsion (Fig. 7G). We also transfected neurons with expression constructs for either wild-type FAK (WT-FAK) or a mutant FAK (FAK-Y397/861F) that cannot be phosphorylated on tyrosine residues 397 and 861. Expression of mutant FAKY397/861F, but not WT-FAK, also abolished MAGinduced repulsion (Fig. 7E-G). Together, these findings demonstrated that MAG-induced phosphorylation of FAK is essential for growth cone turning responses to MAG.

\section{Discussion}

We provided biochemical and functional evidence that $\beta 1$-integrin acts as a direct receptor to mediate MAG- 

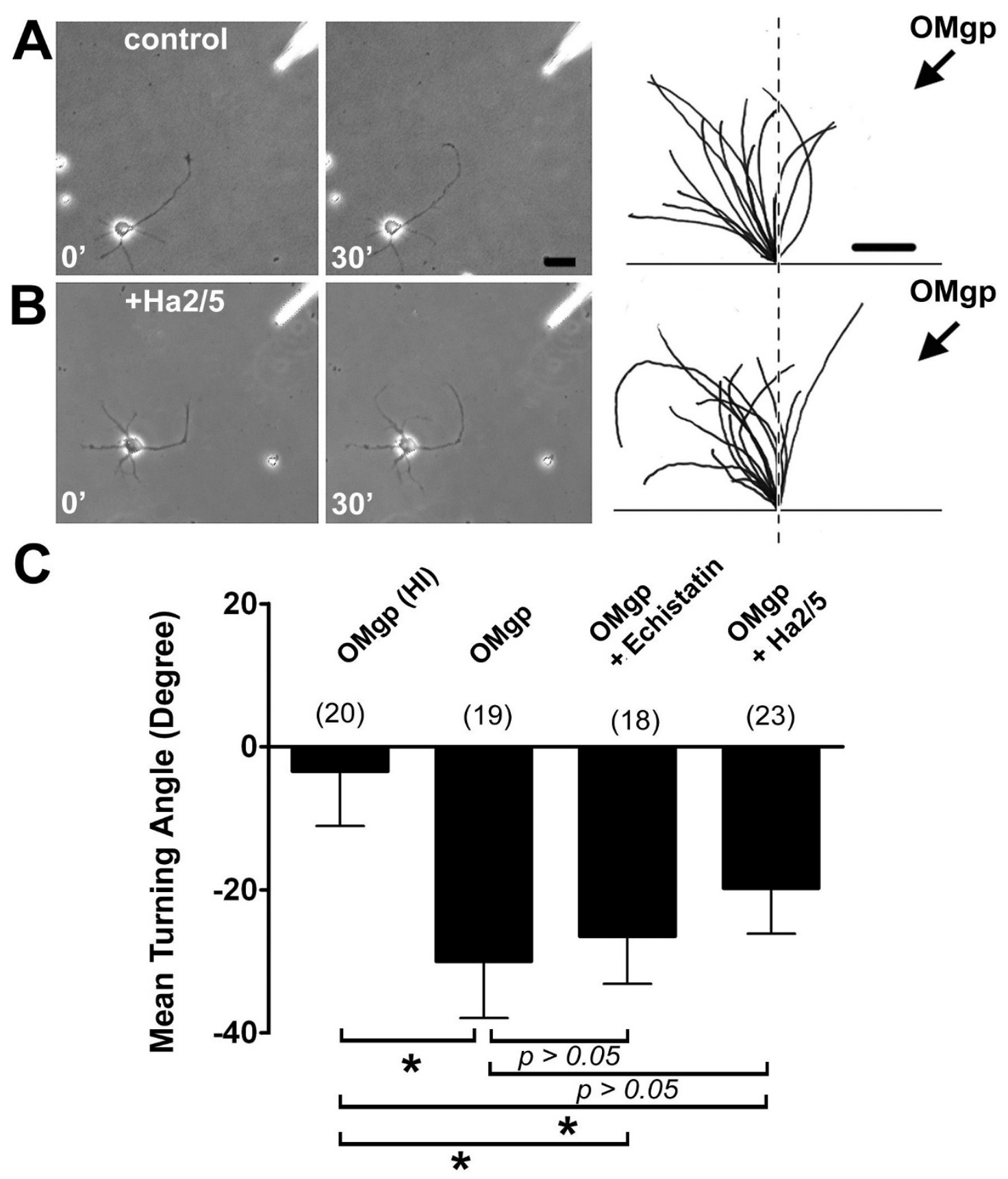

Figure 5

OMgp-induced growth cone repulsion does not require $\beta I$-integrin function. A. Growth cone turning of rat hippocampal neurons in a gradient of OMgp. Sample images show an axon of a P5 hippocampal neuron in an OMgP gradient (5 $\mu$ g/ml in the pipette) at the onset $\left(0^{\prime}\right)$ and at the end $\left(30^{\prime}\right)$ of the turning assay. Scale bar: $20 \mu \mathrm{m}$. Right traces show sample trajectories of axons during the turning assay from 15 randomly selected neurons. Scale bar: $5 \mu \mathrm{m}$. B. Growth cone turning in a gradient of OMgp in the presence of a blocking antibody to $\beta \mathrm{I}$-integrin. Similar as in (A), except for the presence of $\mathrm{Ha} / 5$ (I.0 $\mu \mathrm{g} / \mathrm{ml})$. C. Summary of growth cone turning angles under different conditions. Echistatin ( $100 \mathrm{nM})$ or Ha2/5 (I $\mu \mathrm{g} / \mathrm{ml}) \mathrm{was}$ preincubated for $30 \mathrm{~min}$ and present throughout the turning assay. Values represent mean \pm s.e.m. Numbers associated with the bar graph indicate the number of growth cones analyzed. "*" indicates significant difference from the heat-inactivated $(\mathrm{HI}) \mathrm{OMgP}(p<$ 0.0I, ANOVA). 
A

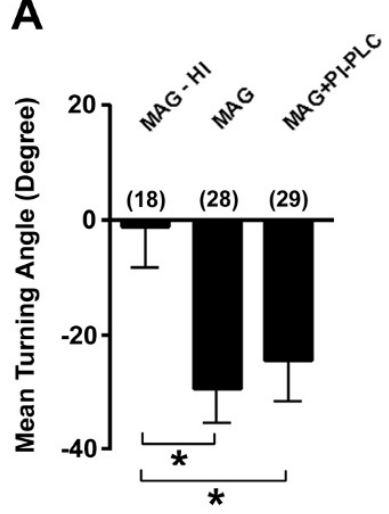

B

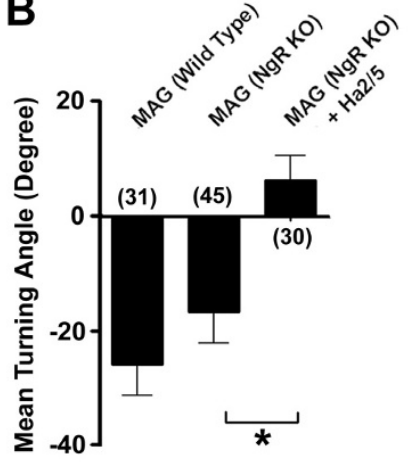

Figure 6

NgRs are dispensable for MAG-induced growth cone repulsion of hippocampal neurons. A. MAG-induced growth cone turning after the PI-PLC treatment. Primary hippocampal neurons were pre-treated with PI-PLC (I unit/ml) for $30 \mathrm{~min}$ at $37^{\circ} \mathrm{C}$ and then growth cones were examined in a gradient of MAG. Shown is the summary of turning angles of axons with or without the PI-PLC treatment. B. MAGinduced growth cone turning of hippocampal neurons from $\mathrm{NgR}$ knockout mice and WT littermates. Shown is the summary of turning angles for axonal growth cones of P5 mouse hippocampal neurons derived from wild-type or NgR knockout $(\mathrm{NgR} \mathrm{KO})$ mice in a gradient of MAG $(150 \mu \mathrm{g} / \mathrm{ml}$ in the pipette) with or without $\mathrm{Ha} 2 / 5(1.0 \mu \mathrm{g} / \mathrm{ml})$ in the bath. Values represent mean \pm s.e.m. Numbers associated with the bar graph indicate the number of growth cones analyzed. "*" indicates significant difference ( $p<0.0$ I, ANOVA).

induced growth cone responses of mammalian CNS neurons from both embryonic and postnatal stages. We further showed that $\beta 1$-integrin signaling mediates MAG effects through FAK phosphorylation and is independent of NgR. Taken together, these results demonstarted a common role of $\beta 1$-integrin in mediating MAG signaling for diverse functions in different neuronal types.

Previous studies led to the finding that Nogo66, OMgp and MAG, three major inhibitors associated with myelin, all bind to NgR and appear to signal at axonal growth cones through a common receptor complex containing NgR, p75/TROY and Lingo-1 [11-19]. Two additional human homologs of NgR (NgR2 and NgR3) are found to be expressed in CNS neurons [52,53]. While neither binds to Nogo66 [54], NgR2 appears to bind to MAG [55]. Accumulating evidence suggests that inhibitors associated with myelin may signal independent of NgRs [20-22]. Our growth cone turning results using NgR null neurons and PI-PLC treatment are in agreement with these findings (Fig. 6). MAG has also been reported to inhibit neurite outgrowth through sialoglycoproteins $[49,56]$ and gangliosides $[23,57]$ in postnatal DRG neurons and cerebellar granule neurons. Our results with the RAD mutant that has an intact arginine residue to mediate the binding of MAG to sialic acids [49] (Fig. 2) but failed to induce growth cone responses suggest a specific requirement of $\beta 1$-integrin in MAG signaling. Whether sialic acids of sialoglycoproteins and gangliosides serve as a co-receptor together with $\beta 1$-integrin to mediate MAG signaling remains to be determined [58].

Integrin signaling has been shown to be critical for axon guidance and cell migration, either as a direct receptor or as a modulator of guidance signaling [26]. Laminins, when presented as substrates for integrins, are known to promote neurite outgrowth [59] and have been shown to override inhibitory activities of MAG and myelin-associated factors [31,32]. It is possible that, in addition to the growth promoting activity of laminin, competitions at the receptor levels by laminins and MAG may also contribute to the enhancement of neurite initiation and outgrowth $[60,61]$. Our results also support the notion that integrin signaling plays an instructive, rather than permissive role, in MAG-induced growth cone turning (Fig. 3). Activation of the integrin/FAK pathway is normally associated with enhanced nerve growth/growth cone attraction [26,62]. Interestingly, $\beta 1$-integrin signaling is required for both MAG-induced repulsion and attraction of CNS neurons at different developmental stages and under different cellular status (Fig. 4; [see Additional file 2]). A recent study also showed that inhibition of neurite outgrowth by fibrinogen requires $\beta 3$-integrin function [63]. Taken together, these findings suggest a bi-functional role of integrin/FAK signaling in regulating the dynamics of cytoskeletal proteins. Our results show that $\beta 1$-integrin serves as a specific receptor for MAG, but not for OMgp. Consistent with the selective involvement of $\beta 1$-integrin in mediating MAG effects, human and rodent MAG contain a RGD-tri-peptide motif characteristic of integrin binding proteins [33,34], whereas OMgp and Nogo do not. Interestingly, MAG homologs in fugu and Zebrafish, species with the capacity for axonal regeneration, do not contain an intact RGD motif (Fig. 1). The extent to which different receptors mediate distinct effects of MAG in various species remains to be determined. Our results further demonstrate that integrin/FAK signaling mediates MAG effects independent of the NgR receptor complex. These findings suggest that a diversity of signaling mechansims is likely to be employed to limit axon regeneration in the adult CNS. Given the general role of $\beta 1$-integrin in mediating diverse functions of MAG in the adult central nervous system, our findings may have implications for novel strategies for therapeutic modulation of MAG functions in the adult nervous system.

Our results show that $\beta 1$-integrin serves as a specific receptor for MAG, but not for OMgp. Consistent with the selec- 


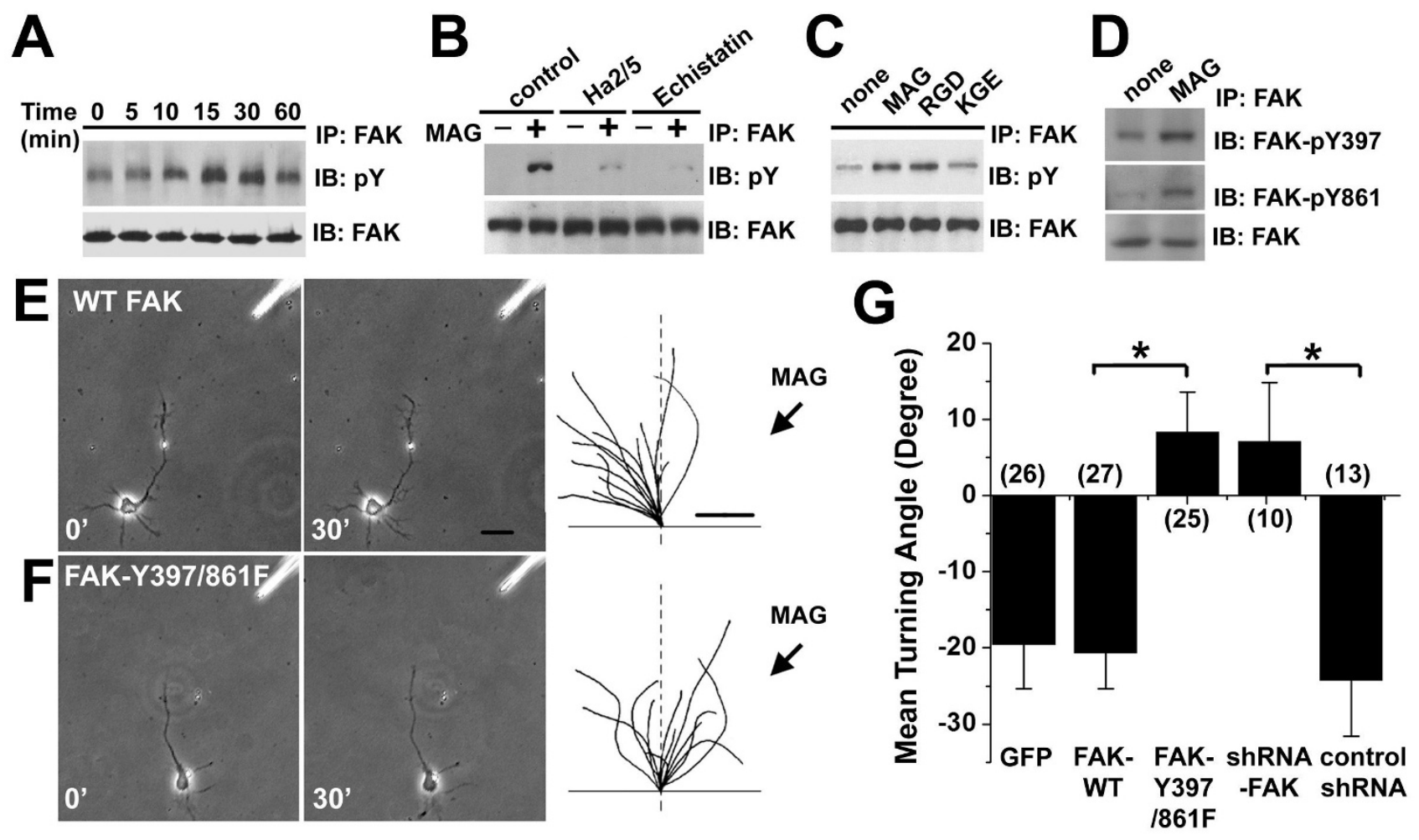

\section{Figure 7}

MAG-induced tyrosine phosphorylation of FAK is required for growth cone repulsion to MAG. A-C. MAG induces phosphorylation of FAK. Shown in (A) is the time course of FAK phosphorylation after MAG stimulation (2 $\mu \mathrm{g} / \mathrm{ml})$ of rat hippocampal neurons. Cell lysates were immunoprecipitated with anti-FAK antibodies and immunoblotted with the pY-20 antibody for phosphorylated tyrosine residues. Shown in (B) are experiments in the presence or absence of Ha2/5 (I.0 $\mu \mathrm{g} / \mathrm{ml})$ or echistatin (I00 nM). Shown in (C) are experiments with the treatment of WT-MAG (RGD) or mutant MAG (KGE). D. MAG induces phosphorylation of FAK on residues Y397 and Y86I. Cell lysates of hippocampal neurons after MAG stimulation were immunoprecipitated with anti-FAK antibodies and immunoblotted with tyrosine phosphorylation site-specific antibodies to FAK. E-G, Phosphorylation of FAK on residues Y397 and Y86I is required for MAG-induced growth cone repulsion. Hippocampal neurons were transfected with expression constructs for GFP, WT-FAK-GFP (E), FAK-Y397/86IF-GFP (F), GFP and control shRNA, GFP and shRNAs against FAK. Growth cones of GFP+ neurons were examined in a gradient of MAG (I50 $\mu g /$ $\mathrm{ml}$ in the pipette). Sample images and traces were shown similarly as in Fig. 2 (A-C). Scale bar: $20 \mu \mathrm{m}$ for microscopic images and $5 \mu \mathrm{m}$ for traces. Shown in $(\mathrm{G})$ is the summary of growth cone turning angles. Values represent mean \pm s.e.m. Numbers associated with the bar graph indicate the number of growth cones analyzed. "*" indicates significant difference from the control (neurons transfected to express GFP alone; $p<0.0$ I, ANOVA).

tive involvement of $\beta 1$-integrin in mediating MAG effects, human and rodent MAG contain a RGD-tri-peptide motif characteristic of integrin binding proteins [33,34], whereas OMgp and Nogo do not. Interestingly, MAG homologs in fugu and Zebrafish, species with the capacity for axonal regeneration, do not contain an intact RGD motif (Fig. 1). The extent to which different receptors mediate distinct effects of MAG in various species remains to be determined. Our results further demonstrate that integrin/FAK signaling mediates MAG effects independent of the NgR receptor complex. These findings suggest that a diversity of signaling mechansims is likely to be employed to limit axon regeneration in the adult CNS.
Given the general role of $\beta 1$-integrin in mediating diverse functions of MAG in the adult central nervous system, our findings may have implications for novel strategies for therapeutic modulation of MAG functions in the adult nervous system.

\section{Methods}

\section{Primary neuronal cultures}

Hippocampal neurons were isolated from the hippocampi embryonic and postnatal rats, or wild-type and $\mathrm{NgR}$ knockout mice [21] as previously described [64]. Similarly, cerebellar neurons were isolated from $P 5$ rat cerebellum [45]. Dissociated neurons were cultured on poly-L- 
lysine coated plates or coverslips without laminin as previously described [64]. For biochemical analysis, E18 neurons were treated with AraC to eliminate dividing astrocytes and used at 5 days after plating as previously described [64]. For growth cone turning assay, neurons were used between 2-3 days after plating. PI-PLC ( 1 or 2 units/ml)[14], Ha2/5 (1 $\mu \mathrm{g} / \mathrm{ml})$ or echistatin (100 $\mathrm{nM})$ [42] were added 30 mins prior to and were present during the growth cone turning assay.

\section{Expression constructs and neuronal transfection}

Mutation of MAG-Fc was generated by site directed mutagenesis and confirmed by DNA sequencing. Expression plasmids of wild-type MAG (RGD) or mutant forms of MAG (KGE, RAD) were transfected into 293 Ebna cells and proteins were collected from the media and affinity purified using protein A sepharose. MAG-Fc from R \& D systems was also used. The pUEG vector was used to coexpress GFP (under the control of the EF1 $\alpha$ promoter) and a specific shRNA (under the control of the human U6 promoter in the same vector) $[65,66]$. Several shRNAs against different regions of $\beta 1$-integrin or FAK, and control shRNA against DsRed [65] were generated. The following short-hairpin sequences were cloned into pUEG vector using a PCR SHAGing strategy [67]: shRNA-control: AGTTCCAGTACGGCTCCAA; shRNA- $\beta 1$-integrin-3: TGC CTACTTCTGCACGATG; shRNA-FAK1: GCACGTGGCCTGCTATGGA; shRNA-FAK2: GCCTTAACAATGCGTCAGT; and shRNA-FAK3: TCCAGAAGACAGGCTACCG. To validate the specificity and efficiency of shRNAs, pUEG vectors with different shRNAs were transfected into 3T3 cells and cell lysates were prepared for western blot analysis of $\beta 1$-integrin or FAK expression with specific antibodies, respectively.

Rat primary hippocampal neurons were transfected with the Amaxa transfection system following protocols from the manufacturer. Briefly, hippocampal neurons were isolated and $100 \mu \mathrm{l}$ of nucleofector solution was added to resuspend the cell pellet. Different expression constructs $(1-5 \mu \mathrm{g})$ for GFP, WT-FAK-GFP, FAK-Y397/861FGFP[68], WT-Rho-GFP, DN-Rho-GFP, or pUEG vectors for shRNAs $[65,66]$, were added to the cell suspension and the cell-DNA mix was then transferred to cuvettes for electroporation. The cells were cultured in DMEM with 10\% fetal bovine serum for 24 hrs before changing to the serum-free neurobasal medium [64]. GFP+ neurons were identified for the turning assay.

\section{Biochemistry}

Neurons at 5 days after plating were treated with 2 units/ ml PI-PLC, $100 \mathrm{nM}$ Echistatin or $0.5-2.0 \mu \mathrm{g} / \mathrm{ml} \mathrm{Ha} / 5$, and then stimulated with $2.0 \mu \mathrm{g} / \mathrm{ml} \mathrm{MAG} \mathrm{or} 0.5 \mu \mathrm{g} / \mathrm{ml}$ OMgp for the indicated time periods. Cells were then lysed in immunoprecipitation buffer (1\% Triton X-100;
$150 \mathrm{mM} \mathrm{NaCl} ; 10 \mathrm{mM}$ Tris, $\mathrm{pH}$ 7.4; $1 \mathrm{mM}$ EDTA; $1 \mathrm{mM}$ EGTA; $1 \%$ Nonidet P-40; $0.2 \mathrm{mM} \mathrm{Na}_{3} \mathrm{VO}_{4} ; 1 \mu \mathrm{g} / \mathrm{ml}$ protease inhibitor cocktail; and $0.1 \mathrm{mM}$ PMSF). Samples were immunoprecipitated with polyclonal antibody against FAK (Santa Cruz Biotechnology, Inc.), human Fc (Sigma) or $\beta 1$-integrin (Chemicon), and then subjected to western blot analysis. The following antibodies were used: monoclonal antibody against tyrosine phosphorylated proteins (pY20, Transduction Laboratories; 1:1000), rabbit polyclonal antibodies against $\beta 1$-integrin (1:1000), FAK (1:1000), FAK-pY397 (Biosource; 1:1000), FAK-pY861 (Biosource; $1: 1000)$, or human Fc $(1: 1000)$. Blots were stripped and reblotted with the same antibodies used for their immunoprecipitation to ensure equal loading of the immunoprecipitated proteins.

For GST pull-down experiments, the extracellular domain (ECD) of $\beta 1$-integrin was amplified from mouse brain cDNA and cloned into the GST-fusion expression vector (pGEX-4T-1; Amersham-Pharmacia Biotech) to express GST- $\beta 1$ (ECD) fusion protein. The fusion protein was purified using glutathione beads according to the manufacturer's manual (Amersham-Pharmacia Biotech). Native Fc fragment $(2 \mu \mathrm{g} / \mathrm{ml})$ or MAG-Fc $(2 \mu \mathrm{g} / \mathrm{ml})$ was then added to the purified GST- $\beta 1$ (ECD) overnight at $4{ }^{\circ} \mathrm{C}$. The samples were further processed according to the standard immunoprecipitation protocol as described.

For experiments testing potential interactions between $\beta 1$ integrin and the $\mathrm{NgR}$ receptor complex, HEK293 cells were transfected with expression constructs for NgR, p75, TROY, or Lingo-1, respectively, as previously described [18]. Transfected cells were stimulated with MAG (5 $\mu \mathrm{g} /$ $\mathrm{ml}$ ) or medium and then were immunoprecipitated with anti- $\beta 1$-integrin antibodies and immunoblotted for respective components of the $\mathrm{NgR}$ receptor complex. Total cell lysates were also examined to show the expression of endogenous $\beta 1$-integrin and proteins from transfection.

\section{Growth cone turning assay}

Microscopic gradients of recombinant MAG $(150 \mu \mathrm{g} / \mathrm{ml}$ in the pipette; $1.8 \mu \mathrm{M})$ and OMgp ( $5 \mu \mathrm{g} / \mathrm{ml}$ in the pipette; $0.1 \mu \mathrm{M}$ ) were produced as previously described to induce growth cone turning responses [40,41,45,69]. In some experiments, MAG $(150 \mathrm{ng} / \mathrm{ml})$ was added to the bath solution and microscopic gradients were produced with saline or $\mathrm{Ha} 2 / 5(0.5 \mu \mathrm{g} / \mu \mathrm{l})$ in the pipette. As another control, a gradient of $\mathrm{Ha} 2 / 5(0.5 \mu \mathrm{g} / \mu \mathrm{l}$ in the pipette) was applied in the absence of MAG in the bath. Previous analysis $[69,70]$ have shown that, under standard pulsing conditions, the average concentration of the factor at the growth cone at a distance of $100 \mu \mathrm{m}$ from the pipette tip is about $10^{3}$ fold lower than that in the pipette and the concentration gradient across the growth cone is about 5- 
$10 \%$. Axons were identified as the longest neurite in these cultures at stage 2-3 of hippocampal neurons as previously described [71]. Growth cone assays were carried out for $30 \mathrm{~min}$ at room temperature. The turning angle was defined by the angle between the original direction of neurite extension and a line connecting the position of the center of the growth cone at the onset and the end of the 30 min period. To assure accurate measurement of turning angles, only neurons with axonal extension $>5 \mu \mathrm{m}$ over the $30 \mathrm{~min}$ period were included for analysis.

\section{Competing interests}

The authors declare that they have no competing interests.

\section{Authors' contributions}

ELKG carried out all biochemistry studies. JYK carried out the all growth cone turning assays. KK and $\mathrm{ZH}$ participated in the interaction studies between $\beta 1$-integrin and NgR components. GLM conceived of the study. MTL, ZH, JWG and GLM participated in its design and coordination and helped to draft the manuscript. All authors read and approved the final manuscript.

\section{Additional material}

\section{Additional file 1}

Requirement of $\beta 1$-integrin function in MAG-induced growth cone turning of hippocampal neurons under different conditions. A. Summary of turning angles for axonal growth cones of P5 rat hippocampal neurons expressing control shRNA or shRNA specific against $\beta 1$-integrin, or in the presence of anti- $\beta 3$-integrin antibody. B. Sample western blot for $3 T 3$ cells transfected with vectors expressing control shRNA or specific shRNAs against FAK, and immunoblotted for FAK and $\beta$-actin. Click here for file

[http://www.biomedcentral.com/content/supplementary/17566606-1-10-S1.pdf]

\section{Additional file 2}

Summary of turning angles for embryonic and postnatal axonal growth cones of 17 embryonic and P5 postnatal hippocampal neurons in the presence of pharmacological PKA activator (Sp-cAMPS, 20 $\mu \mathrm{M})$ or inhibitor (Rp-cAMPS, $20 \mu \mathrm{M})$, respectively. Note the conversion of MAG-induced attraction of E17 neurons to repulsion by inhibition of PKA and conversion of MAG-induced repulsion of P5 neurons to attraction by activation of PKA. Importantly, all MAG-induced turning responses were abolished by the bath application of $\mathrm{Ha2} / 5(1.0 \mu \mathrm{g} / \mathrm{ml})$. Values represent mean \pm s.e.m. Numbers associated with the bar graph indicate the number of growth cones analyzed. "* " indicates significant difference $(\mathrm{p}<0.01$, ANOVA).

Click here for file

[http://www.biomedcentral.com/content/supplementary/17566606-1-10-S2.pdf]

\section{Additional file 3}

Effects of the PI-PLC treatment on hippocampal neurons. A. Effective removal of $\mathrm{NgR}$ from primary hippocampal neurons by the PI-PLC treatment. Primary hippocampal neurons were transfected with the empty vector or vector expressing NgR-FLAG. Cultures with or without the PI-PLC treatment ( 1 unit $/ \mathrm{ml}$ for 30 min at $37^{\circ} \mathrm{C}$ ) were subjected to western blot analysis using antibodies against the FLAG tag. The membrane was reblotted for GADPH to show similar loading. B. The PI-PLC treatment does not affect binding of MAG to $\beta 1$-integrin in hippocampal neurons. Hippocampal neurons were treated with saline or PI-PLC (1 units $/ \mathrm{ml})$ for 30 min at $37^{\circ} \mathrm{C}$, then stimulated with MAG $(1 \mu \mathrm{g} / \mathrm{ml})$ for $15 \mathrm{~min}$. Cell lysates were immunoprecipitated with anti- $\beta 1$ integrin antibodies and immunoblotted with anti-Fc antibodies. The membrane was reblotted for $\beta 1$-integrin to show similar loading.

Click here for file

[http://www.biomedcentral.com/content/supplementary/17566606-1-10-S3.pdf]

\section{Additional file 4}

Lack of interaction between $\beta 1$-integrin and members of the known $\mathrm{NgR}$ receptor complex. Lysates of HEK293 cells transfected with expression constructs for $\mathrm{NgR}, \mathrm{p75}, \mathrm{TROY}$, or Lingo-1, with or without MAG treatment $(5 \mu \mathrm{g} / \mathrm{ml})$, were immunoprecipitated with anti- $\beta 1$-integrin antibodies and immunoblotted for the respective components of the $\mathrm{NgR}$ receptor complex. Also shown are immunoblots for total cell lysates showing the expression of endogenous $\beta 1$-integrin and transfected proteins, and reblots for Fc showing a strong association of MAG and $\beta 1$-integrin in 293 cells.

Click here for file

[http://www.biomedcentral.com/content/supplementary/17566606-1-10-S4.pdf]

\section{Additional file 5}

FAK activation independent of PI-PLC. A. The PI-PLC treatment does not affect MAG-induced phosphorylation of FAK in hippocampal neurons. Hippocampal neurons were treated with saline or PI-PLC (1 units $/ \mathrm{ml})$ for $30 \mathrm{~min}$ at $37^{\circ} \mathrm{C}$, then stimulated with MAG $(1 \mu \mathrm{g} / \mathrm{ml})$ for $15 \mathrm{~min}$. Cell lysates were immunoprecipitated with anti-FAK antibodies and immunoblotted with pY-20 antibody for phosphorylated tyrosine residues. The membrane was reblotted for FAK to show similar loading. B. Knockdown of the expression of endogenous FAK by specific shRNAs. Sample western blot of $3 T 3$ cells were transfected with vectors expressing control shRNA or specific shRNAs against FAK, and then immunoblotted for FAK and $\beta$ actin.

Click here for file

[http://www.biomedcentral.com/content/supplementary/17566606-1-10-S5.pdf]

\section{Acknowledgements}

We thank David Ginty, Alex Kolodkin and Ronald Schnaar for critical reading of the manuscript, Lihong Liu and Kurt Sailor for technical help. Supported by grants from the Adelson Medical Research Foundation, the Culpeper Scholarship in Medical Science, March of Dimes, Klingenstein Fellowship Award in the Neuroscience, and National Institute of Health (NS04827I) to G-I. M.

\section{References}

I. Johnson PW, Abramow-Newerly W, Seilheimer B, Sadoul R, Tropak MB, Arquint M, Dunn RJ, Schachner M, Roder JC: Recombinant myelin-associated glycoprotein confers neural adhesion and neurite outgrowth function. Neuron 1989, 3:377-385. 
2. McKerracher L, David S, Jackson DL, Kottis V, Dunn RJ, Braun PE: Identification of myelin-associated glycoprotein as a major myelin-derived inhibitor of neurite growth. Neuron 1994, | 3:805-8| |.

3. Mukhopadhyay G, Doherty P, Walsh FS, Crocker PR, Filbin MT: A novel role for myelin-associated glycoprotein as an inhibitor of axonal regeneration. Neuron 1994, 13:757-767.

4. Schafer M, Fruttiger M, Montag D, Schachner M, Martini R: Disruption of the gene for the myelin-associated glycoprotein improves axonal regrowth along myelin in C57BL/WIds mice. Neuron 1996, 16:1107-1113.

5. De Bellard ME, Filbin MT: Myelin-associated glycoprotein, MAG, selectively binds several neuronal proteins. J Neurosci Res 1999, 56:213-218.

6. Turnley AM, Bartlett PF: MAG and MOG enhance neurite outgrowth of embryonic mouse spinal cord neurons. Neuroreport 1998, 9:1987-1990.

7. Filbin MT: Myelin-associated inhibitors of axonal regeneration in the adult mammalian CNS. Nat Rev Neurosci 2003, 4:703-7I3.

8. He Z, Koprivica V: The Nogo signaling pathway for regeneration block. Annu Rev Neurosci 2004, 27:34I-368.

9. Kim J, Schafer J, Ming GL: New directions in neuroregeneration. Expert Opin Biol Ther 2006, 6:735-738.

10. Tang S, Qiu J, Nikulina E, Filbin MT: Soluble myelin-associated glycoprotein released from damaged white matter inhibits axonal regeneration. Mol Cell Neurosci 200I, 18:259-269.

II. Fournier AE, GrandPre T, Strittmatter SM: Identification of a receptor mediating Nogo-66 inhibition of axonal regeneration. Nature 200I, 409:34I-346.

12. Domeniconi M, Cao Z, Spencer T, Sivasankaran R, Wang K, Nikulina E, Kimura N, Cai H, Deng K, Gao Y, He Z, Filbin M: Myelin-associated glycoprotein interacts with the Nogo66 receptor to inhibit neurite outgrowth. Neuron 2002, 35:283-290.

13. Liu BP, Fournier A, GrandPre T, Strittmatter SM: Myelin-associated glycoprotein as a functional ligand for the Nogo-66 receptor. Science 2002, 297: I190-1193.

14. Wang KC, Koprivica V, Kim JA, Sivasankaran R, Guo Y, Neve RL, He $Z$ : Oligodendrocyte-myelin glycoprotein is a Nogo receptor ligand that inhibits neurite outgrowth. Nature 2002, 417:941-944.

15. Wang KC, Kim JA, Sivasankaran R, Segal R, He Z: P75 interacts with the Nogo receptor as a co-receptor for Nogo, MAG and OMgp. Nature 2002, 420:74-78.

16. Wong ST, Henley JR, Kanning KC, Huang KH, Bothwell M, Poo MM: A p75(NTR) and Nogo receptor complex mediates repulsive signaling by myelin-associated glycoprotein. Nat Neurosci 2002, 5:1302-1308.

17. Mi S, Lee X, Shao Z, Thill G, Ji B, Relton J, Levesque M, Allaire N, Perrin S, Sands B, Crowell T, Cate RL, McCoy JM, Pepinsky RB: LINGO$I$ is a component of the Nogo-66 receptor/p75 signaling complex. Nat Neurosci 2004, 7:22I-228.

18. Park JB, Yiu G, Kaneko S, Wang J, Chang J, He XL, Garcia KC, He Z: A TNF receptor family member, TROY, is a coreceptor with Nogo receptor in mediating the inhibitory activity of myelin inhibitors. Neuron 2005, 45:345-35I.

19. Shao Z, Browning JL, Lee X, Scott ML, Shulga-Morskaya S, Allaire N, Thill G, Levesque M, Sah D, McCoy JM, Murray B, Jung V, Pepinsky RB, Mi S: TAJ/TROY, an orphan TNF receptor family member, binds Nogo-66 receptor I and regulates axonal regeneration. Neuron 2005, 45:353-359.

20. Niederost B, Oertle T, Fritsche J, McKinney RA, Bandtlow CE: Nogo-A and myelin-associated glycoprotein mediate neurite growth inhibition by antagonistic regulation of RhoA and Racl. I Neurosci 2002, 22:10368-10376.

21. Zheng B, Atwal J, Ho C, Case L, He XL, Garcia KC, Steward O, Tessier-Lavigne M: Genetic deletion of the Nogo receptor does not reduce neurite inhibition in vitro or promote corticospinal tract regeneration in vivo. Proc Natl Acad Sci USA 2005, 102: $1205-1210$

22. Chivatakarn O, Kaneko S, He Z, Tessier-Lavigne M, Giger RJ: The Nogo-66 receptor NgRI is required only for the acute growth cone-collapsing but not the chronic growth-inhibitory actions of myelin inhibitors. J Neurosci 2007, 27:7 I I7-7I 24.

23. Mehta NR, Lopez PH, Vyas AA, Schnaar RL: Gangliosides and Nogo receptors independently mediate myelin-associated glycoprotein inhibition of neurite outgrowth in different nerve cells. J Biol Chem 2007, 282:27875-27886.

24. Hynes RO: Integrins: bidirectional, allosteric signaling machines. Cell 2002, I 1 0:673-687.

25. Ridley AJ, Schwartz MA, Burridge K, Firtel RA, Ginsberg MH, Borisy G, Parsons JT, Horwitz AR: Cell migration: integrating signals from front to back. Science 2003, 302: I 704-1709.

26. Nakamoto T, Kain KH, Ginsberg MH: Neurobiology: New connections between integrins and axon guidance. Curr Biol 2004, I4:RI2I-I23.

27. Davy A, Robbins SM: Ephrin-A5 modulates cell adhesion and morphology in an integrin-dependent manner. Embo J 2000, 19:5396-5405.

28. Serini G, Valdembri D, Zanivan S, Morterra G, Burkhardt C, Caccavari $F$, Zammataro L, Primo L, Tamagnone L, Logan M, TessierLavigne M, Taniguchi M, Puschel AW, Bussolino F: Class 3 semaphorins control vascular morphogenesis by inhibiting integrin function. Nature 2003, 424:39|-397.

29. Gomez TM, Robles E, Poo M, Spitzer NC: Filopodial calcium transients promote substrate-dependent growth cone turning. Science 200I, 29 I: 1 983-1987.

30. Stevens A, Jacobs JR: Integrins regulate responsiveness to slit repellent signals. I Neurosci 2002, 22:4448-4455.

31. David S, Braun PE, Jackson DL, Kottis V, McKerracher L: Laminin overrides the inhibitory effects of peripheral nervous system and central nervous system myelin-derived inhibitors of neurite growth. J Neurosci Res 1995, 42:594-602.

32. Laforest S, Milanini J, Parat F, Thimonier J, Lehmann M: Evidences that betal integrin and Racl are involved in the overriding effect of laminin on myelin-associated glycoprotein inhibitory activity on neuronal cells. Mol Cell Neurosci 2005, 30:418-428.

33. Ruoslahti $E$ : RGD and other recognition sequences for integrins. Annu Rev Cell Dev Biol 1996, I 2:697-7I5.

34. Ruoslahti E, Pierschbacher MD: New perspectives in cell adhesion: RGD and integrins. Science 1987, 238:49|-497.

35. May AP, Robinson RC, Vinson M, Crocker PR, Jones EY: Crystal structure of the $\mathrm{N}$-terminal domain of sialoadhesin in complex with 3' sialyllactose at I.85 A resolution. Mol Cell 1998, I:719-728.

36. Zaccai NR, Maenaka K, Maenaka T, Crocker PR, Brossmer R, Kelm S, Jones EY: Structure-guided design of sialic acid-based Siglec inhibitors and crystallographic analysis in complex with sialoadhesin. Structure (Camb) 2003, I I:557-567.

37. Pedraza L, Owens GC, Green LA, Salzer L: The myelin-associated glycoproteins: membrane disposition, evidence of a novel disulfide linkage between immunoglobulin-like domains, and posttranslational palmitylation. J Cell Biol 1990, I I I:265 I-266 I.

38. Sadoul R, Fahrig T, Bartsch U, Schachner M: Binding properties of liposomes containing the myelin-associated glycoprotein MAG to neural cell cultures. J Neurosci Res 1990, 25: I- 13.

39. Henley JR, Huang KH, Wang D, Poo MM: Calcium mediates bidirectional growth cone turning induced by myelin-associated glycoprotein. Neuron 2004, 44:909-916.

40. Shim S, Goh EL, Ge S, Sailor K, Yuan JP, Roderick HL, Bootman MD, Worley PF, Song H, Ming GL: XTRPCI-dependent chemotropic guidance of neuronal growth cones. Nat Neurosci 2005, 8:730-735.

4I. Song H, Ming G, He Z, Lehmann M, McKerracher L, Tessier-Lavigne $M$, Poo M: Conversion of neuronal growth cone responses from repulsion to attraction by cyclic nucleotides. Science 1998, $281: 1515-15 \mid 8$.

42. Gan ZR, Gould RJ, Jacobs JW, Friedman PA, Polokoff MA: Echistatin. A potent platelet aggregation inhibitor from the venom of the viper, Echis carinatus. J Biol Chem 1988, 263: I 9827-19832.

43. Mendrick DL, Kelly DM: Temporal expression of VLA-2 and modulation of its ligand specificity by rat glomerular epithelial cells in vitro. Lab Invest 1993, 69:690-702.

44. Yip PM, Zhao X, Montgomery AM, Siu CH: The Arg-Gly-Asp motif in the cell adhesion molecule $L I$ promotes neurite outgrowth via interaction with the alphavbeta3 integrin. Mol Biol Cell 1998, 9:277-290.

45. Xiang Y, Li Y, Zhang Z, Cui K, Wang S, Yuan XB, Wu CP, Poo MM, Duan S: Nerve growth cone guidance mediated by $\mathbf{G}$ proteincoupled receptors. Nat Neurosci 2002, 5:843-848. 
46. Hopker VH, Shewan D, Tessier-Lavigne M, Poo M, Holt C: Growthcone attraction to netrin- $I$ is converted to repulsion by laminin-I. Nature 1999, 40 I:69-73.

47. Cai D, Qiu J, Cao Z, McAtee M, Bregman BS, Filbin MT: Neuronal cyclic AMP controls the developmental loss in ability of axons to regenerate. J Neurosci 200I, 2 I:473 I-4739.

48. Cai D, Shen Y, De Bellard M, Tang S, Filbin MT: Prior exposure to neurotrophins blocks inhibition of axonal regeneration by MAG and myelin via a cAMP-dependent mechanism. Neuron 1999, 22:89-101.

49. Tang S, Shen YJ, DeBellard ME, Mukhopadhyay G, Salzer JL, Crocker PR, Filbin MT: Myelin-associated glycoprotein interacts with neurons via a sialic acid binding site at ARG I I 8 and a distinct neurite inhibition site. J Cell Biol 1997, I38: I 355-I366.

50. Nikolopoulos SN, Giancotti FG: Netrin-integrin signaling in epithelial morphogenesis, axon guidance and vascular patterning. Cell Cycle 2005, 4:e I3I-I35.

5I. Xie Z, Tsai LH: Cdk5 phosphorylation of FAK regulates centrosome-associated miocrotubules and neuronal migration. Cell Cycle 2004, 3: 108-I I0.

52. Lauren J, Airaksinen MS, Saarma M, Timmusk T: Two novel mammalian Nogo receptor homologs differentially expressed in the central and peripheral nervous systems. Mol Cell Neurosci 2003, 24:58I-594.

53. Pignot V, Hein AE, Barske C, Wiessner C, Walmsley AR, Kaupmann K, Mayeur H, Sommer B, Mir AK, Frentzel S: Characterization of two novel proteins, NgRH I and NgRH2, structurally and biochemically homologous to the Nogo-66 receptor. I Neurochem 2003, 85:717-728.

54. Barton WA, Liu BP, Tzvetkova D, Jeffrey PD, Fournier AE, Sah D, Cate R, Strittmatter SM, Nikolov DB: Structure and axon outgrowth inhibitor binding of the Nogo-66 receptor and related proteins. Embo J 2003, 22:3291-3302.

55. Venkatesh K, Chivatakarn O, Lee H, Joshi PS, Kantor DB, Newman BA, Mage R, Rader C, Giger RJ: The Nogo-66 receptor homolog NgR2 is a sialic acid-dependent receptor selective for myelin-associated glycoprotein. J Neurosci 2005, 25:808-822.

56. DeBellard ME, Tang S, Mukhopadhyay G, Shen YJ, Filbin MT: Myelinassociated glycoprotein inhibits axonal regeneration from a variety of neurons via interaction with a sialoglycoprotein. Mol Cell Neurosci 1996, 7:89-10I.

57. Vyas AA, Patel HV, Fromholt SE, Heffer-Lauc M, Vyas KA, Dang J, Schachner M, Schnaar RL: Gangliosides are functional nerve cell ligands for myelin-associated glycoprotein (MAG), an inhibitor of nerve regeneration. Proc Natl Acad Sci USA 2002, 99:84I 2-84I7.

58. Cao Z, Qiu J, Domeniconi M, Hou J, Bryson JB, Mellado W, Filbin MT: The inhibition site on myelin-associated glycoprotein is within Ig-domain $\mathbf{5}$ and is distinct from the sialic acid binding site. J Neurosci 2007, 27:9|46-9|54.

59. Condic ML, Letourneau PC: Ligand-induced changes in integrin expression regulate neuronal adhesion and neurite outgrowth. Nature 1997, 389:852-856.

60. Grimpe B, Dong S, Doller C, Temple K, Malouf AT, Silver J: The critical role of basement membrane-independent laminin gamma I chain during axon regeneration in the CNS. J Neurosci 2002, 22:3|44-3160.

6I. Hu F, Strittmatter SM: The N-terminal domain of Nogo-A inhibits cell adhesion and axonal outgrowth by an integrin-specific mechanism. J Neurosci 2008, 28: |262-1269.

62. Giancotti FG, Ruoslahti E: Integrin signaling. Science 1999, 285: $1028-1032$.

63. Schachtrup C, Lu P, Jones LL, Lee JK, Lu J, Sachs BD, Zheng B, Akassoglou K: Fibrinogen inhibits neurite outgrowth via beta3 integrin-mediated phosphorylation of the EGF receptor. Proc Natl Acad Sci USA 2007, 104: 1 1814-1 1819.

64. Song H, Stevens CF, Gage FH: Astroglia induce neurogenesis from adult neural stem cells. Nature 2002, 417:39-44.

65. Ge S, Goh EL, Sailor KA, Kitabatake Y, Ming GL, Song H: GABA regulates synaptic integration of newly generated neurons in the adult brain. Nature 2006, 439:589-593.

66. Duan X, Chang JH, Ge S, Faulkner RL, Kim JY, Kitabatake Y, Liu XB, Yang CH, Jordan JD, Ma DK, Liu CY, Ganesan S, Cheng HJ, Ming GL, Lu B, Song H: Disrupted-In-Schizophrenia I regulates integration of newly generated neurons in the adult brain. Cell 2007, I30: | |46-1 I58.
67. Paddison PJ, Caudy AA, Bernstein E, Hannon GJ, Conklin DS: Short hairpin RNAs (shRNAs) induce sequence-specific silencing in mammalian cells. Genes Dev 2002, I 6:948-958.

68. Ren XR, Ming GL, Xie Y, Hong Y, Sun DM, Zhao ZQ, Feng Z, Wang Q, Shim S, Chen ZF, Song HJ, Mei L, Xiong WC: Focal adhesion kinase in netrin-I signaling. Nat Neurosci 2004, 7: I 204- 1212.

69. Zheng JQ, Felder M, Connor JA, Poo MM: Turning of nerve growth cones induced by neurotransmitters. Nature 1994, 368: $140-144$.

70. Lohof AM, Quillan M, Dan Y, Poo MM: Asymmetric modulation of cytosolic CAMP activity induces growth cone turning. J Neurosci 1992, I 2:|253-126|.

7I. Dotti CG, Sullivan CA, Banker GA: The establishment of polarity by hippocampal neurons in culture. I Neurosci 1988, 8:|454-|468.
Publish with Bio Med Central and every scientist can read your work free of charge

"BioMed Central will be the most significant development for disseminating the results of biomedical research in our lifetime. "

Sir Paul Nurse, Cancer Research UK

Your research papers will be:

- available free of charge to the entire biomedical community

- peer reviewed and published immediately upon acceptance

- cited in PubMed and archived on PubMed Central

- yours - you keep the copyright

Submit your manuscript here:

http://www.biomedcentral.com/info/publishing_adv.asp
BioMedcentral 